\title{
A Profile of an Effective EFL Writing Teacher (A Technology-based Approach)
}

\author{
Zohreh Seifoori \\ Ph.D. in TEFL, Department of English Language \\ Tabriz Branch, Islamic Azad University, Tabriz, 51575-5311, Iran \\ E-mail: zseifoori2005@yahoo.com \\ Mohammad Amin Mozaheb (Corresponding author) \\ Ph.D. Student in TEFL, Young Researchers Club \\ Tabriz Branch, Islamic Azad University, Tabriz, 51575-5311, Iran \\ E-mail: mozaheb.ma@gmail.com \\ Amir Biglar Beigi \\ Ph.D. in TEFL, Department of English Language \\ Ershad-Damavand Institute of Higher Education, Tehran, Iran \\ E-mail: amirbiglarbeigi@yahoo.com
}

Received: February 2, 2012

Accepted: February 21, 2012

Published: May 1, 2012

doi:10.5539/elt.v5n5p107

URL: http://dx.doi.org/10.5539/elt.v5n5p107

\begin{abstract}
Teaching writing has always been a controversial issue in the field of Foreign Language Teaching. And while there are a number of approaches and techniques for teaching writing in an English as a Second Language or English as a Foreign Language (SL/EFL) setting, very few comprehensive frameworks exist for an ESL/EFL writing teacher. The present study hopes to fill that void by exploring the qualities of a good and effective EFL writing teacher on the basis of classroom observation and interviews. The classroom teaching of an Iranian EFL writing teacher, whose students and colleagues consider him a successful EFL writing teacher,was observed for about 1680 minutes.He was observed with intent to isolate the pedagogical skills that make him stand out. The result of the observation shows that there are some specific features for a successful writing teacher to be bear in mind by other EFL practitioners teaching the same classes. Finally, this study provides some guidelines for the effective teaching of writing in an EFL context, which will also be useful for ESL/EFL teachers in their classrooms.
\end{abstract}

Keywords: Modeled writing, Guided writing, Effective EFL teaching, Successful composition (writing teacher), Qualitative approach

\section{Introduction}

EFL/ESL writing is a difficult, complex and challenging process (Alsamadani, 2010). This difficulty and complexity in ESL/EFL writing arise from the fact that writing includes discovering a thesis, developing support for the thesis, organizing, revising, and finally editing the thesis to ensure an effective, error-free piece of writing (Langan, 2005). Additionally, ESL/EFL writing is one of the most important aspects of language teaching.As Lee (2003, p. 112) asserts, "it is likely that most business and technical writing in the world is done in a second language." GoodESL/EFL writing is the main concern for teachers, researchers, textbook writers and program designers in the field of Foreign Language Teaching (Lee, 2003), but crafting a text for most ESL/EFL students is difficult because the writing process calls for a wide range of cognitive and linguistic strategies of which ESL/EFL students are mostly unaware (Luchini, 2010). Moreover, research about EFL/ESL writing has grown dramatically over the last 40 years, specifically between the late 1980s and the early 1990s. As a consequence, writing has now become an interdisciplinary field of inquiry (Matsuda, 2003). Historically, there are three major types of ESL/EFL writing approaches. They areproduct approach (Brown, 2001; Harmer, 2007; Hyland, 2002; Silva; 1990), process approach (Brown, 2001; Raimes, 1985; Silva, 1993; Wang, 2000; You, 2004) and genre-based approach (Casanave, 2004; 
Deng, 2007; Harmer, 2007; Hyland, 2003a; Hyland, 2003b;Leki, 2003).

In the product approach students are supposed to produce the correct textual form that conforms to the model provided by their teacher. As the name suggests, in this approach, the final product (that is, the linguistic form) takes precedence over the process of learning to produce the product. In other words, under product approach, students are taught to "develop competence in particular modes of written communication by deconstructing and reconstructing model texts" (Christmas, 2011, p.1).Traditionally, this approach was used by many ESL/EFL teachers all around the world. As Robertson (2008) posits, "teacher-centeredness is often amplified if instructors organize their curriculum by means of a 'product approach' where instructors teach to and evaluate from sample, "ideal" texts" (p.53).Furthermore, Brown (2001) asserted that in product approach, successful learning is measured by how well-structured and grammatically correct a composition is. It is also important to note that in product-based approach, students rarely acquire the skills required for creating and shaping their work because of the overemphasis on linguistic forms (Robertson, 2008).

In contrast to the product approach, the process approach mainly focuses on the stages of writing such asplanning, drafting, revisiting or redrafting and editing (Harmer, 2007). In other words, the process approach has a constructivist view of the author; it sees the author as a communal learner and communicator (Murray, 1980). The constructivist theory, which focuses on the importance of social interaction on learning, was first introduced by Russian psychologist Lev Vygotsky (1978). As is well-known in the psychological literature, Vygotsky's theory owes debts to Piaget's (1969) cognitive-constructivists view of learners. Moffett (1992) merged Vygotsky's and Piaget's theories to propound his own theory of discourse genre, which "focuses on the act of writing from the perspective of author (and reader) in relationship to experience, measuring the rhetorical distance at which an author describes, reports, generalizes and/or theorizes about a given situation or event" (Robertson, 2008, p.55). In the process approach to learning methods play pivotal roles and the learning can be regarded as non-linear and discursive.

The last but not least approach is the genre-based approach, which focuses on social contexts (Widodo, 2006). In this approach, writing is not only a linguistic and social activity; it is also a social act (Santoso, 2010). In other words, students are expected to present their work to a particular audience in a particular context, and with a certain purpose (Santoso, 2010). Success in communication is measured by the extent to which a type of written organization and layout is recognized by the members of a discourse community (Paltridge, 2006) because the community members share the same language customs and norms (Harmer, 2007). Table 1 below summarizes the main orientations towards teaching writing in an EFL context.

Regarding EFL writing orientations, there are a number of approaches for teaching writing. They include modeling, shared, guided, independent and interactive writing. Table 2 below summarizes these writing approaches.

Understanding all of the above-mentioned points about different orientations in EFL writing is critical to the success of a good writing teacher. Put in other way, a good EFL writing teacher should know about different approaches of writing. As a matter of fact, an effective writing teacher should be aware of the historical and experimental orientations in EFL writing and be able to use them at the appropriate times. As Martin (2011) stresses, the teacher should act as a facilitator of the learning process in writing classes. Murray (1985, p.13) also observes that"the teacher has to restrain himself or herself from providing the content, taking care not to inhibit the students from finding their own meaning, their own subjects, their own forms and their own language." However, the teachers should be cautious about performing a type of "Carl Rogers Therapy" in writing courses where the teacher only listens and nods his/her head in agreement (Carnecelli, 1980). Given these, Tsui (2003) mentions three dimensions to measure the effectiveness of expert language teachers:

(a) How they relate to the act of teaching, and the extent to which they integrate or dichotomize the various aspects of teacher knowledge in the teaching act,

(b) How they relate to specific contexts of work, and the extent to which they are able to perceive and open up possibilities that do not present themselves as such in their specific contexts of work, and

(c) The extent to which they are able to theorize the knowledge generated by their personal practical experience as teachers and to put theoretical knowledge into practice (p.247).

Generally speaking, there are also some other characteristics for an effective language teacher such as being a good manager, being patient, being enthusiastic, being flexible, and being intelligent (Baleghizadehand Mozaheb, 2011). Additionally, West (2010) proposed a set of features for effective EFL teachers, which are presented in table 3 below.

In view of the features of an effective teacher outlined above, the authors of the present study intend to find the 
characteristics of a good EFL writing teacher. A lot of research has been done on effective ways of teaching writing to ESL/EFL students; however, the extant literature fails to focus on teachers themselves. What is it that effective teachers do in their writing classes? What teaching and learning behaviors are important for a good writing teacher? This studyanswers these questions.

Classroom situations play an important role for effective teaching. As van Lier (1998, p. 23) notes, "We thus have the curious situation that most second language acquisition theorizing ignores the L2 classroom as a relevant source of data and as relevant place to apply findings." Additionally, in research studies in classroom settings, only those dimensions of a teacher's behavior which are quantifiable seem to have been taken into account by Teaching of English as a Foreign Language (TEFL) community member. Such research studies are quantitative in nature. However, Dornyei (2007) believes that both qualitative and quantitative research methods are critical to ESL/EFL stakeholders and researchers. Qualitative research studies are interpretive in nature. As Mackey and Gass (2005, p. 2) assert, "qualitative studies... are not set up as experiments; the data cannot be easily quantifiable... and the analysis is interpretive rather than statistical." This study uses no quantitative measures. It lays bare the techniques of successful teaching of EFL writing through a series of observations and interviews with someone that has been adjudged an effective EFL writing teacher.

\section{The Present Study}

The main aims of the current study are to utilize observational and interview techniques to learn more about EFL teaching of writing and to develop a profile for an effective writing teacher in an EFL setting. Berliner (1984) and Blum (1984) considered the issue of effective teaching a familiar topic in EFL research studies. They hold that learners from effective teachers achieve higher than expected levels of performance on standardized achievement tests. Additionally, reports collected from supervisors, faculty deans, and colleagues are used to select an effective teacher. In the present study, there were some critical reasons for concentrating on this particular teacher's class for about 14 sessions, some of which were:

1. About 40 of his colleagues considered him the best teacher of the faculty.

2. Compared with his colleagues who had taught EFL writing in university, he had a positive impression towards teaching writing. It is also important to note that at the time of carrying out this study, there were about $5 \mathrm{EFL}$ writing teachers at the university that considered the subject of this study the best writing teacher they had ever seen in Iran.

3. All of the 250 students of the university were eager to attend his classes.

4. The head of the university also considered him an important and successful teacher.

5. The head of English department of the university had a positive attitudes towards his teaching.

\section{Research Questions}

What are the key features of an effective EFL writing teacher?

How can an effective writing teacher assist his/her students improve their writing skills?

\section{Method}

An EFL writing teacher agreed to be observed on a regular time schedule. The observational data consisted of video-taping of class lectures and interviews with the teacher. The main objective for observing and interviewing the teacher was to find out his techniques for teaching EFL writing and the reasons for his success in teaching writing. The aim of the interview was to more intimately uncover his attitude toward teaching writing and to gain a deep appreciation of the strategies he used in classroom settings.

\subsection{Participants}

The teacher participated in this study completed his Ph.D. in Teaching English as a Foreign Language (TEFL) at the University of Malaya (UM) in Kuala Lumpur, Malaysia. He regularly taught a writing course (composition) for undergraduate students majoring English Translation and English Literature. The class was held two sessions a week, each for about 120 minutes.

\subsection{Procedure}

The general goals and objectives of this course have already been set in by the Iran's Ministry of Science, Research and Technologies. However, the teacher added his own objectives to the course, which he included in the syllabus he handed out to students. Some of the objectives are reported in the following section:

1. Students will gain the ability to write an informal letter/email utilizing the common letter format with a salutation and a closing section. 
2. When writing two or more paragraphs, students will learn to be cautious about the use of commas, periods and capitalization.

3. Students will learn to write a paragraph with a topic sentence in addition to supporting sentences and a concluding sentence.

4. Students will learn to use simple transition words in order to make their texts more coherent.

5. Student will learn to use the conjunctions"and" and "but" properly when writing compound subjects.

6. Students will learn to use complex sentences in their writings, i.e., use independent and dependent clauses in different paragraphs.

7. Students will learn to improve their EFL writing ability by using journal writing.

8. After passing 7 sessions, students will write a composition with an introduction, one or more supporting paragraphs, and a conclusion.

9. Students will write a short composition with more than 5 paragraphs, using chronological/spatial/organizational orders.

10. Students will learn to write a short introduction with a thesis statement.

11. Students will learn to write developmental paragraphs using different instances.

12. Students will learn how to access a variety of collocations in the English language. Additionally, there are different English corpora (plural form of corpus) that students could use to write "natural" English.

13. Students will learn to use modern technologies to improve their editing skills..

14. Students should consider discourse analysis (i.e., cohesion, coherence in sentences) and different contexts in EFL writing courses.

The materials used in this class were a book titled the Practical Writer with Readings by Edward P. Bailey and Philip A. Powell (2007) Additional texts were used in each session by the teacher. Allstudents were also expected to have theOxford Collocations Dictionaryfor Students of English (2006)or the Macmillan Collocations Dictionary (2010) in every session. It is also worth mentioning that all the students used the Web Corpus as the main source for checking different collocations in the World Wide Web.

\subsection{Observation of a Lesson}

In this section, one of the interviews and video recordings of the model teacher will be elaborated on. The lesson discussed here occurred in the seventh session of the class. As was mentioned earlier, the teacher is an expert in TEFL who believes in different approaches for teaching writing i.e., Modeled-Shared-Interactive-Guided-Independent. His perspective on the efficacy of using of different approaches in writing classes is encapsulated in the following words:

"A good teacher should have enough knowledge about different strategies and approaches for teaching writing. In my view, ESL/EFL writing is dynamic in nature and needs lots of time and energy. In other words, we need to use each approach in the right time with the right materials, and this causes the teacher to have the knowledge in advance [...]. Let me tell you in this way: sometimes we need to use modeled writing, which is a teacher-centered approach, and in some cases when the class is ready, we should use other techniques in writing, which are more student-centered like independent or guided writing"

In this session, the teacher used modeled writing. In the modeledwriting method, the teacher plays the most important role. $\mathrm{He} / \mathrm{she}$ writes in front of the students, creates the text, and controls all underlying stages in writing. Additionally, the teacher thinks aloud about different techniques and strategies used in writing. In this approach students can get a feel of the thinking that informs the process of writing. The thoughts can be about the selection of topics, organization of ideas, drafting, fixing of grammar errors, and so on.

There were a number of activities in this lesson. The main criteria forthe activities were based on Oczkus's (2007, p.17) viewpoints, which say that the teacher should go through the following stages in the Modeling approach:

Brainstorm your own topic of interest. You can write the idea on the board or use some slides for introducing it. Tell students that good writers often write about their own experiences.

Select one of your entries and tell why you are choosing it. Select a topic and then tell students the reasons behind your selection.

Begin webbing ideas and details around your selected topic. Tell students to ask you questions.. 
Write your weekend journal entry. Begin writing and try to give enough information about each sentence,

Reread your own writing. Tell students that rereading is a key technique for good writers.

Add to the rubric. Ask students' ideas about what you have written and try to add their viewpoints to your writing.

Introduce cool tools. Check student understanding via thumbs-up or thumbs-downsignals.

Assess student progress. Are your students ready to write on their own? Do they need guided writing or can they start independent writing?

\subsection{Some Hints about the Lesson}

The teacher turns on the video projector and a number of slides appear on the board. These are different topics for writing, i.e., last weekend, my garden, and my favorite job. The teacher asks the students about their favorite topic and "my last weekend" is selected as the topic. Now the teacher thinks aloud about the topic.

T: I really love trips. This is really an interesting topic. This was so special I want to recall my journey in full details....

Now the teacher wants students to ask him different questions about the topic. The students ask thequestions that follow below. In this step, students sought information from the teacher.

S1: Where did you go last weekend?

S2: Can you name some of the historical places that you enjoyed in Isfahan [a city located about $340 \mathrm{~km}$ south of Tehran, the federal capital]?

S3: How did you go? I mean you went with a bus or airplane?

S4: Can you name some of the [the student does not know the word souvenir, so he asks the right word in his native language from the teacher] souvenirs? I mean what did you buy?

S5: How was the weather?

S6: Did you see any tourist there?

S7: Can you name some of the cities around Isfahan?

Now the teacher starts writing and he tries to talk as he writes each sentence. In other words, he clicks the mouse and with each click a sentence appears on the board. He visualizes different details as a way to remember them.

T: Good writers reread as they revise and think of what to write next.

The teacher writes these sentences on the board.

T: [...] Arriving in Isfahan around 6 a.m., I left the warmth of the bus and went into the bus terminal to wait for the sun to come up so that the weather would be warm enough to continue my trip. The name of the terminal is Soffeh[it is the name of a mountain near the city]... Eventually the sun rose and I set off into the city, relying on my inbuilt GPS to find the neat stuff Isfahan had to offer. I walked a good $5 \mathrm{~km}$, sometimes stopping for a sleep in a park or to eat, and somehow bypassing entirely the center of the city. I began to wonder if Isfahan was all it was cracked up to be. Then, finally I came across the HashtBeresht [8 Paradises] palace, and its surrounding park, and reassurance came. (The original text was extracted from TravelPod.com, 2011, p.1)

Then the teacher asks thestudents to add some important points about the city of Isfahan.

The teacher asks these questions to test the students' level of understanding.

T: Did I include enough detail here?Do I need to use another verb here?

The next stage is to check different words in the Webcorp corpus. For instance, all the students checked the word "set up" to see different collocations that are linked to this word.

The next step is the students' writing. Here the teacher believes that the best way to encourage good writing is to use the technique of shared writing in which students help the teacher in writing about the journey. For instance, a volunteer goes to the board and writes different sentences with contributions from his friends. Another strategy the teacher deployed was guided writing. This strategy requires students to read their pieces aloud for the class and for other students tolook out for errors and suggestions to correct the errors (Oczkus's, 2007).

The teacher thendetermines the right time for independent writing. He "circulates through the room while the students write and try to assist them" (Oczkus's, 2007, p.75). The teacher we observed for this study opined that the strategies suggested by Cunningham et al. $(2002$, p.12) should be utilized. He said students should choose one of the following conditions: 
1. working in a group with you [teacher]

2. working in pairs and talking about their writing as they go

3. working independently at their desks

\section{Data Analysis and Results}

The main goal of observing this teacher's composition class was to attempt to find out the events of the classroom and why students and his colleagues called him a successful teacher. Evaluation and interpretation of each lesson need lots of time and endeavor. In order to do this, the observer should be as objective as possible by bracketing his biases and prejudices. The following principles were taken out from the deep analysis of the video recordings and the written reports of each session and form the basis for considering this teacher as a successful EFL composition teacher.

1. The teacher is an avid reader who is up-to-date with new strategies and approaches to writing in ESL/EFL settings. This is an important issue to be considered by all teachers and EFL/ESL practitioners in this daywhen modern technologies and the Internet make accessing different sources and lesson plans for language teaching easy for most people in the world. This ease affords EFL/ESL teachers the opportunity to check and find new trends and experiments carried out in the field of TEFL for the purpose of effective teaching of writing.

2. Dedicate enough time to writing while planning your curriculum, and students should be involved in different forms of writing. "Teachers that achieve exceptional success in teaching writing recognize the importance of frequent and sustained writing" (Graham and Perin, 2007, p.5). Each EFL teacher should consider the effect of sustained writing in an EFL setting. In other words, students should write at least an hour in a day in the process of writing, planning, revising, authoring, or publishing texts (Graham, 2008). Further, students should email their writings to their teacher for feedback. The teacher can bring some of the samples to the next class to show different errors and suggestions for correcting the errors..

3. Students should have enough knowledge about writing. An effective writing teacher should tell students about the characteristics of good writing and also acquaint them with different forms and purposes of writing in an EFL context (Graham, 2008). To achieve this goal, teachers should provide students with different models of writing and let them know how the writers manipulate different texts and paragraphs while writing. Another important facilitator is the encouraging of students to read different texts written for different purposes, i.e., "communicating (writing personal letters, cards), informing others (describing an event, writing reports), reflecting about self (autobiography) and learning content materials (summarizing, learning logs)" (Graham, 2008, p.5).

4. Motivate students by using authentic and real-life texts. Another critical issue is the use of authentic materials in writing.For instance, an effective writing teacher can bring authentic models of writing from different books, journals, newspapers, and magazines. This can motivate students to learn in an EFL setting. An effective teacheralso celebrates his/her students'success by praising them, as the following teacher-student conversation from our study illustrates:

T: Dear Behnam, read your writing, please?

S: Yes, sir. May I start?

T: Yes, of course.

\section{S: The Open Source Castle}

When I was younger and I did not know anything about Linux, which is an open source operating system.It was my bro who introduced me to the realm of the open source community.

It was then that I realized what a unique phenomenon I did nothing about so far in my life; I can remember how spectacular it was and, believe it or not, it still is.

The way other members were willing to answer others at once; you could feel the pure openness.

Anyhow, it was just how the long journey has begun and, to be perfectly honest, I am still enjoying it all the more.

T: Excellent! Your effort has been rewarded. Your style is great, let us check it again sentence by sentence and see if you need any modification....

5. Teach students to be strategic writers. Learners can use think sheets or graphic organizers for planning, drafting, revising, or editing (Graham \&Perin, 2007; Rogers \& Graham, in press).Additionally, students can foster their writing ability by utilizing brainstorming and semantic webbing (Graham \& Harris, 2005; Harris, Graham, Mason, \&Freidlander, 2008). 
6. Pair work and group work are supplementary activities for teaching writing. An effective writing teacher should use pair work and group work where he/she considers them to be useful. For example, in guided writing, it is not easy to start with independent writing when students are in need of pair work and group work. The use of different writing approaches can make the writing class more motivating and more communicative. Another advantage of pair work / group work is that it helps students easily internalize newly learned material. Finally, it helps students learn to work independently (Baleghizadehand Mozaheb, 2011).

7. An effective teacher uses recent technologies and corpus-based learning in his/her classes. Using computers and video-projectors in writing classes can be very useful.For instance, the use of word processors can help students foster their writing ability. As Graham and Perin, (2007) summarized, the advantages of using computer in writing classes are:"(1) revisions can be made easily, (2) the resulting paper can be presented in a variety of professional-looking formats, and (3) typing provides an easier means of producing text"(p.8). Another important issue is the use of corpus-based programs in writing classes. Students can learn a lot when checking different collocations and when checking their own errors and mistakes via the Internet. They can type their words in different search engine motors and find the words in context.

8. A good writing teacher should use integrative approaches while teaching. A good teacher should be able to consider the needs of the students and then decide on the right approach to be used in his/her classes.

9. An effective composition teacher should introduce the concept of discourse for students and integrate it into writing programs. To put it simply, cohesion and coherence should be regarded as important factors for EFL writing classes. As Thornbury (2010, p. 25) stressed,"teachers need to move from sentence-based to text-based teaching to help students achieve their real world communicative goals."Language always occurs in texts and discourse (Thornbury, 2005). Accordingly, Liu (2000) posits that cohesion and coherence are two important features in writing classes especially in teaching academic writing.

10. An effective teacher considers students' needs and then chooses the best assessment. Assessment is an important part of writing classes. Teachers need to know the two strategies traditionally used for assessing writing i.e., peer assessment and subjective assessment. Good assessment can lead teachers to find students who are in need of more instruction and help. Assessment should be done by both teachers and students to increase understanding of newly learned materials (Harris, Graham, \& Mason, 2006).

\section{Discussion}

Considering the main qualities of an effective writing teacher in EFL settings, it is critical to note thateffective written communication should be the ultimate goalof writing classes. This is even more so in the teaching of writing in ESL/EFL situations. Recent studies in teaching and assessing writing support this conclusion ( e.g., Concha \&Paratore, 2011; Hafner, 2010; Kuhi\&Behnam, 2011; Laquintano, 2010; Leijten, 2011; Maxwell-Reid, 2011; McCutchen, 2011; Suzuki, 2011; Thompson, 2009; Van Hout, 2011 ). When thinking of an effective EFL teacher in general, one may list a number of features. These features can be sorted in a more specific manner when listing the qualities of an effective EFL writing teacher. As a matter of fact,the ideal characteristics of an effective writing teacher are determined by different situations. As mentioned previously, the main aim of the present study was to delineate a holistic framework for assessing the qualities of a good composition teacher. Future studies can investigate other features ofeffective teaching of EFL composition that this study may have overlooked.

Both qualitative and quantitative studies are important in TESOL/TEFL. The present study was a qualitative one.Dornyei (2007, p. 34) argues quantitative "proponents usually emphasize that at its best quantitative inquiry is systematic, rigorous, focused, and tightly controlled, involving precise measurement and producing reliable and replicable data that is generalizable to other concepts."However, Strauss and Corbin (1998, p. 34) point out that "Qualitative and quantitative forms of research both have roles to play in theorizing." The qualitative method is the best suited for investigating the main characteristics of an effective EFL writing teacher. Effective composition teaching cannot be conveyed through the use of quantitative measures. The researcher needs to shed some light on the philosophical orientations and theories in Foreign Language Teaching, thus making qualitative inquiry the best method.

\section{Conclusion and Implication}

In sum, the present study succeeded in explicating a part of a complex whole. To make the inquiry more completeit is suggested that further studies be conducted. For instance, more time and energy are needed to observe more composition classes and to interview more EFL writing teachers. Another interesting line of research would be to record the attitudes of teachers and students alike in advance before observing classroom sessions. Given that what teachers believe and what they practice may differ focusing only on beliefs and not investigating how the 
participating teachers actually teach writing only provideshalf the story. Researchers would need to collect data showing what teachers actually do about writing in their classes. Because attitudes and beliefs are half of the story and what is happening in the classroom can complete our investigation. It is hoped that other researchers in the field of TESOL/TEFL would concentrate on this issue.

\section{References}

Alsamadani, H. A. (2010). The Relationship between Saudi EFL Students' Writing Competence, L1 Writing Proficiency, and Self-regulation. European Journal of Social Sciences, 16(1), 53-63.

Bailey, E. P., \& Powell, PH. A. (2007). The practical writer with readings. New York: Heinle.

Baleghizadeh, S., \& Mozaheb, M. A. (2011). A profile of an effective EFL grammar teacher. Journal of Language Teaching and Research, 2(2), 364-369. http://dx.doi.org/10.4304/jltr.2.2.364-369

Berliner, D. (1984). The half-full glass: A review of research on teaching. In P. Hosford (Ed.), Using what we know about teachers (pp. 51-84). Alexandria, VA: Association for Supervision and Curriculum Development.

Blum, R. E. (1984). Effective schooling practices: a research synthesis. Portland, Ore: Northwest Regional Educational Laboratory.

Bradly, Ch. (2011). The role of brainstorming in improving student writing performance in the EFL classrooms. [Online] Available: http://www.edwarddebono.com (October 14, 2011).

Brown, H. D. (2001). Teaching by principles: An interactive approach to language pedagogy (2nd ed). California: San Francisco State University.

Carnecelli, TH. A. (1980). The Writing conference: A one-to-one conversation. In Timothy R. Donovan and Ben W. McClelland (eds.), eight approaches to teaching composition, Chapter 7, pp. 101-131. Urbana, IL: National Council of Teachers of English.

Casanave, C. P. (2004). Controversies in second Language writing: Dilemmas and decisions in research and instruction. Ann Arbor, MI: The University of Michigan Press.

Christmas, B. (2011). The role of brainstorming in improving students writing performance in the EFL classroom. [Online] Available: http://sydney.edu.au/cet/docs/research/The\%20Role\%20of\%20Brainstorming\%20in\%20Improving\%20Students\%2 0Writing.pdf (October 12, 2011).

Concha, S., \& Paratore, R. (2011). Local Coherence in Persuasive Writing: An Exploration of Chilean Students' Metalinguistic Knowledge, Writing Process, and Writing Products. Written Communication, 28, 34-69. http://dx.doi.org/10.1177/0741088310383383

Cunningham, P., Cunningham, J., \& Allington, R. (2002). Research on the components of a comprehensive reading and writing instructional program. [Online] Available: http://www.wfu.edu/ cunningh/fourblocks/ (October 14, 2011).

Deng, X. (2007). A pedagogical response to the different approaches to the teaching of ESL/EFL Essay writing. STETS Language \& Communication Review, 6(1), 15-20.

Dörnyei, Z. (2007). Research methods in applied linguistics. Oxford: Oxford University Press.

Farr, S. (2010). Teaching as leadership: The Highly Effective Teacher's Guide to Close the Achievement Gap. San Francisco: Jossey-Bass Publication.

Graham, S., \& Harris, K. R. (2005). Writing better: teaching writing processes and self-regulation to students with learning problems. Baltimore: Brookes.

Graham, S., \& Perin, D. (2007). What we know, what we still need to know: Teaching adolescents to write. Scientific Studies in Reading, 11, 313-336.

Hafner, A. CH. (2010). A Multi-perspective Genre Analysis of the Barrister's Opinion: Writing Context, Generic Structure, and Textualization. Written Communication, 27, 410-441. http://dx.doi.org/10.1177/0741088310377272

Harmer, J. (2007). The practice of English language teaching. (4th edition). Harlow: Longman. http://dx.doi.org/10.1177/003368820103200109

Harris, K. R., Graham, S., Mason, L., \& Friedlander, B. (2008). Powerful writing strategies for all students. Baltimore: Brookes.

Hyland, K. (2002). Teaching and researching writing. New York: Longman. 
Hyland, K. (2003a). Second language writing. Cambridge, UK: Cambridge University Press.http://dx.doi.org/10.1017/CBO9780511667251

Hyland, K. (2003b). Genre-based pedagogies: A social response to process. Journal of Second Language Writing, 12, 1-29. http://dx.doi.org/10.1016/S1060-3743(02)00124-8

Kuhi, D., \& Behnam, B. (2011). Generic variations and metadiscourse use in the writing of applied linguists: a comparative study and preliminary framework. Written Communication, 28, 97-141. http://dx.doi.org/10.1177/0741088310387259

Langan, J. (2005). College Writing Skills. Atlantic Cape Community College: McGraw Hill.

Laquintano, T. (2010). Sustained Authorship: Digital Writing, Self-Publishing, and the Ebook. Written Communication, 27, 469-493. http://dx.doi.org/10.1177/0741088310377863

Lee, S. (2003). Teaching EFL Writing in the University: Related Issues, Insights, and Implications. Journal of National Taipei Teachers College, 16(1), 111-136.

Leijten, M., De Maeyer, S., \& Van Waes, L. (2011). Coordinating sentence composition with error Correction: A multilevel analysis. Journal of Writing Research, 2(3), 331-363.

Leki, L. (2003). Coda: Pushing L2 writing research. Journal of second Language Writing, 12, 103-105. http://dx.doi.org/10.1016/S1060-3743(02)00128-5

Liu, D. (2000). Writing cohesion: Using content lexical ties in ESOL. English Teaching Forum, 38(1), 28-35.

Luchini, P. L. (2010). Evaluating the effectiveness of a complimentary approach to teaching writing skills. International Journal of Language Studies (IJLS), 4(3), 73-92.

Mackey, A., \& Gass, S. M. (2005). Second language research: methodology and design. Mahwah, NJ: Lawrence Erlbaum.

Macmillan Collocation Dictionary. (2010). London : Macmillan.

Martin, D. (2010). ESL Essay Writing. [Online] Available: http://www.how-to-teach-english-in-japan.com/ esl-essay-writing.html (October, 2011).

Matsuda, P. K. (2003). Second language writing in the twentieth century: A situated historical perspective. In B. Kroll (Ed.), Exploring the dynamics of second language writing (pp. 15-34). Cambridge: Cambridge Applied Linguistics Series.

Maxwell-Reid, C. (2011). The Challenges of Contrastive Discourse Analysis: Reflecting on a Study into the Influence of English on Students' Written Spanish on a Bilingual Education Program in Spain. Written Communication, 28, 417-435.

McCutchen, D. (2011). From Novice to Expert: Implications of Language Skills and Writing-Relevant Knowledge for Memory during the Development of Writing Skill. Journal of WritingResearch, 3(1), 51-68.

Moffett, J. (1992). Detecting growth in language. New Hampshire: Boynton/Cook.

Murray, D. M. (1980). Writing as a process: How writing finds its own meaning. In Timothy R. Donovan and Ben W. McClelland (eds), Eight approaches to teaching composition (pp. 90-100). Urbana, IL: National Council of Teachers of English.

Murray, D. M. (1980). Writing as process: How writing finds its own meaning. In T.R. Donovan \& B.W. McClelland (Eds.), Eight approaches to teaching composition (pp. 3-20). Urbana, IL: National Council of Teachers of English.

Oczkus, D. L. (2007). Guided writing. Porthmouth: Heinemann

Oxford Collocation Dictionary. (2009). Oxford: Oxford University Press.

Paltridge, B. (2006). Discourse analysis: an introduction. London : Continuum.

Piaget, J. (1969). Science of the education and the psychology of the child. New York: Viking.

Raime, A. (1985). What unskilled ESL students do as they write: A classroom study of composing. TESOL Quarterly, 19, 229-258.

Robertson, C. (2008). Integration of Moodle Course Management System (CMS) into an EFL Writing Class. The JALT CALL Journal, 4(1), 53-59.

Rogers, L., \& Graham, S. (in press). A meta-analysis of single subject design writing intervention research. Journal of Educational Psychology. http://dx.doi.org/10.1037/0022-0663.100.4.879 
Santoso, A. (2010). Scaffolding an EFL effective writing class in a hybrid learning community. Unpublished Ph.D. dissertation. Queensland: Queensland University of Technology.

Silva, T. (1990). Second language composition instruction: Developments, issues, and directions in ESL. In B. Kroll (Ed.), Second language writing (pp. 11-23). Cambridge: Cambridge University Press.

Silva, T. (1993). Towards an understanding of the distinct nature of L2 writing: The ESL research and its implications. TESOL Quarterly, 27, 756-777. http://dx.doi.org/10.2307/3587400

Strauss, A., \& Corbin, J. (1998). Basics of qualitative research: techniques and procedures for developing grounded theory (Second edition). Thousand Oaks, CA: Sage.

Suzuki, Sh. (2011). Perceptions of the qualities of written arguments by Japanese students. Written Communication, 28, 380-402. http://dx.doi.org/10.1177/0741088311420798

Thompson, I. (2009). Scaffolding in the Writing Center: A Microanalysis of an Experienced Tutor's Verbal and Nonverbal Tutoring Strategies. Written Communication, 26, 417-453.http://dx.doi.org/10.1177/0741088309342364

Thornbury, S. (2005). Beyond the sentence: Introducing Discourse Analysis. London: Macmillan.

Thornbury, S. (2010). What can a corpus tell us about discourse? The Routledge Handbook of Corpus Linguistics. London: Routledge.

Travelpod. (2011). Isfahan. [Online] Available: http://blog.travelpod.com/travel-blog-entries/ashventures/ 1/1290097240/tpod.html\#ixzz1dzTxDnMw (October, 2011).

Tsui, A. B. M. (2003). Understanding expertise in teaching: Case studies of ESL teachers. New York: Cambridge University Press.

Van Hout, T. (2011). The Anthropology of Writing. Understanding Textually-Mediated Worlds. Journal of Writing Research, 3(1), 69-71.

Van Lier, L. (1988). The classroom and the language learner: Ethnography and second language classroom Research. Harlow: Longman.

Vygotsky, L. S. (1978). Mind in society: The development of higher psychological processes. Cambridge, MA: Harvard University Press.

Wang, X. (2004). Encouraging self-monitoring in writing by Chinese students. ELT Journal, 58(3), 238-246.

Webcorp (2011). Webcorp live: Concordance the Web in Real Time. [Online] Available: http://www.webcorp.org.uk/live/search.jsp (October, 2011).

West, T. (2011). How to be an effective EFL teacher. [Online] Available: http://www.onlineteflcourses.com/mod/forum/discuss.php?d=116 (October, 2011).

Widodo, H. P. (2006). Extensive reading in an ESL class in the United States: some good points. Retrieved from: http://www.nus.edu.sg/celc/publications/RELT71/71to76-widodo.pdf

You, X. (2004). The choice made from no choice: English writing instruction in a Chinese university. Journal of Second Language Writing, 13, 97-110. http://dx.doi.org/10.1016/j.jslw.2003.11.001

Table 1. EFL Writing Orientation (From Santoso, 2010)

\begin{tabular}{|l|l|}
\hline EFL Writing Orientation & Treatment of Writing \\
\hline Product Approach & Linguistic Act \\
\hline Process Approach & Cognitive Act \\
\hline Genre-based Approach & Social Act \\
\hline
\end{tabular}


Table 2. Summary of different methods in teaching writing (From Farr, 2010, p.125)

\begin{tabular}{|c|c|c|}
\hline Method & Summary & Tips and Suggestions \\
\hline $\begin{array}{l}\text { Modeled } \\
\text { Writing }\end{array}$ & $\begin{array}{l}\text { Teacher creates, } \\
\text { writes, and thinks } \\
\text { aloud. }\end{array}$ & $\begin{array}{l}\text { - Think aloud constantly, explaining the strategies you use. } \\
\text { - Use expressive language and actions to describe exactly what } \\
\text { you are doing. } \\
\text { Use modeled writing as a mini lesson to introduce new writing } \\
\text { skills and genres. }\end{array}$ \\
\hline $\begin{array}{l}\text { Shared } \\
\text { Writing }\end{array}$ & $\begin{array}{l}\text { Teacher and } \\
\text { students co-create; } \\
\text { teacher writes and } \\
\text { thinks aloud. }\end{array}$ & $\begin{array}{l}\text { - Have your students watch as you transform their thoughts into } \\
\text { written words. } \\
\text { Contribute ideas to the writing, but help students generate ideas } \\
\text { themselves. }\end{array}$ \\
\hline $\begin{array}{c}\text { Interactive } \\
\text { Writing }\end{array}$ & $\begin{array}{l}\text { Teacher and } \\
\text { students co-create } \\
\text { and co-write. }\end{array}$ & $\begin{array}{l}\text { Talk, think aloud, and involve your students when one or more } \\
\text { write. } \\
\text { Have a two way conversation around the creation of words, } \\
\text { sentences or paragraphs. } \\
\text { Move your students to independence by not doing what they can } \\
\text { do for themselves. } \\
\text { Demonstrate the writing in a way that is large enough that all } \\
\text { students in the class can access it and be involved. }\end{array}$ \\
\hline $\begin{array}{l}\text { Guided } \\
\text { Writing }\end{array}$ & $\begin{array}{l}\text { Students create and } \\
\text { write while teacher } \\
\text { closely monitors } \\
\text { and guides process. }\end{array}$ & $\begin{array}{l}\text { Work with the whole class or a small group of students who have } \\
\text { similar needs, as they write a composition. } \\
\text { Observe and assess your students' writing, actively coaching } \\
\text { their skills. } \\
\text { - Ask open ended questions to extend your students thinking in the } \\
\text { process. }\end{array}$ \\
\hline $\begin{array}{l}\text { Independent } \\
\text { Writing }\end{array}$ & $\begin{array}{l}\text { Students create and } \\
\text { write while teacher } \\
\text { monitors progress. }\end{array}$ & $\begin{array}{l}\text { - } \quad \text { Intervene with the writing process only when appropriate. } \\
\text { - } \quad \text { Continue to be involved but let the students' role grow. } \\
\text { - } \quad \text { Assist students with the revision and editing process. }\end{array}$ \\
\hline
\end{tabular}

Table 3. General features of an effective EFL teachers (West, 2010, p.7)

\begin{tabular}{|l|l|}
\hline Learn your students' names & Establish authority from the beginning \\
\hline Be overly prepared & Find out what learners already know \\
\hline $\begin{array}{l}\text { Always consider the learners' needs when } \\
\text { preparing for each lesson. }\end{array}$ & Be prepared to make changes to your lesson plan \\
\hline Be knowledgeable about grammar & Be knowledgeable about the learners' culture \\
\hline $\begin{array}{l}\text { Don't assume that your class textbook has the } \\
\text { language that your students need or want to } \\
\text { learn }\end{array}$ & $\begin{array}{l}\text { Don't assume (falsely) that the class textbook will } \\
\text { work. }\end{array}$ \\
\hline Choose your class textbooks very carefully & Don't neglect useful vocabulary teaching \\
\hline Don't neglect useful vocabulary teaching & Don't neglect the teaching of listening \\
\hline Turn regular activities into games & Motivate your students with variety \\
\hline Show interest in the students as individuals & Allow time for free communication \\
\hline Use humour to liven up the class & Circulate(move around the class) \\
\hline Make your instructions short and clear & Speak up, but don't break anyone's eardrum \\
\hline Don't talk too much & Don't talk too slow \\
\hline Be sensitive to your students & Don't be a psychiatrist \\
\hline Respect both "slow" and "fast" learners & Don't lose your cool \\
\hline Be frank/ Be a coach/ Be reflective & Be fair and realistic in testing \\
\hline Don't overcorrect & Keep in shape (Look at new EFL materials) \\
\hline Laugh at yourself sometimes & \\
\hline
\end{tabular}

